\title{
Is erythrocyte size a strategy to avoid hypoxia in Wiegmann's Torquate Lizards (Sceloporus torquatus)? Field evidence
}

\author{
Juan C. González-Morales, Erendira Quintana, Hector Díaz-Albiter, Palestina Guevara-Fiore, \\ and Victor Fajardo
}

\begin{abstract}
This study examined changes in certain hematological parameters in a reptilian model naturally exposed to altitudeassociated hypoxia. Four populations of the Mexican lizard Sceloporus torquatus Wiegmann, 1828 (Wiegmann's Torquate Lizard) from different altitudes were sampled to evaluate erythrocyte count (Erc), hematocrit (Hct), mean corpuscular hemoglobin concentration (MCHC), and erythrocyte size (Ers). Blood was also assayed to determine hemoglobin ([Hb]), glucose, lactate, and electrolyte concentrations. Erc was performed using a Neubauer hemocytometer. Hct was calculated as percentage of packed cell volume by centrifuging blood samples. [Hb] was determined using a Bausch and Lomb Spectronic colorimeter. MCHC was calculated with the formula $100 \times[\mathrm{Hb}] /$ Hct. Ers was calculated from blood smear microphotographs analyzed with the Sigma Scan Pro software. Values of serum electrolytes ( $\operatorname{sodium}\left(\mathrm{Na}^{+}\right)$, potassium $\left(\mathrm{K}^{+}\right)$, and calcium $\left(\mathrm{Ca}^{2+}\right)$ ), $\mathrm{pH}$, glucose, and lactate from blood samples were obtained through a blood electrolyte analyzer. Highland populations of $S$. torquatus exhibited a significant increase in Erc, Hct, Ers, and [Hb]. In contrast, MCHC showed no correlation with altitude. Additionally, significant differences in lactate, $\mathrm{Na}^{+}, \mathrm{K}^{+}$, and $\mathrm{Ca}^{2+}$ were observed in highland populations. In general, we found that most hematological parameters were significantly different among lizard populations from different altitudes. This is the first study to report changes in Ers in relation to altitude, which could be a physiological response to hypoxia.
\end{abstract}

Key words: erythrocyte, hematological parameters, high altitude, hypoxia, Sceloporus torquatus, spiny lizard.

Résumé : La présente étude se penche sur les modifications de certains paramètres hématologiques dans un modèle de reptile exposé à l'hypoxie associée à l'altitude. Quatre populations du lézard mexicain Sceloporus torquatus Wiegmann, 1828 de différentes altitudes ont été échantillonnées pour évaluer le nombre de globules rouges (Erc), l'hématocrite (Hct), la teneur corpusculaire moyenne en hémoglobine (MCHC) et la taille des globules rouges (Ers). Le sang a également été analysé pour en déterminer les concentrations d'hémoglobine ([Hb]), de glucose, de lactate et d'électrolytes. La numération d'Erc a été effectuée à l'aide d'un hémocytomètre de Neubauer. L'Hct a été calculée en pourcentage par centrifugation des échantillons de sang. La [Hb] a été déterminée à l'aide d'un colorimètre Spectronic de Bausch and Lomb. La MCHC a été calculée selon la formule $100 \times[\mathrm{Hb}] / \mathrm{Hct}$. L'Ers a été calculée à partir de microphotographies de frottis de sang analysées avec le logiciel Sigma Scan Pro. Les teneurs en électrolytes sériques (sodium $\left(\mathrm{Na}^{+}\right)$, potassium $\left(\mathrm{K}^{+}\right)$et calcium $\left(\mathrm{Ca}^{2+}\right)$ ), glucose et lactate et le $\mathrm{pH}$ ont été obtenus à l'aide d'un analyseur d'électrolytes sanguins. La population de haute altitude de $S$. torquatus présentait des augmentations significatives du Erc, de l'Hct, de l'Ers et de la [Hb]. En revanche, la MCHC n'était pas corrélée à l'altitude. En outre, des différences significatives des teneurs en lactate, $\mathrm{Na}^{+}, \mathrm{K}^{+}$et $\mathrm{Ca}^{2+}$ ont été observées dans les populations de haute altitude. En général, nous avons constaté que la plupart des paramètres hématologiques étaient significativement différents pour les populations de lézards de différentes altitudes. Il s'agit de la première étude à faire état de variations de l'Ers en fonction de l'altitude, qui pourraient constituer une réaction physiologique à l'hypoxie. [Traduit par la Rédaction]

Mots-clés : globules rouges, paramètres hématologiques, haute altitude, hypoxie, Sceloporus torquatus, scélopore.

\section{Introduction}

Vertebrates living at high altitude are subjected to hypoxic conditions that challenge their aerobic metabolism. Highland vertebrates usually exhibit functional and structural modifications that allow them to cope with the concomitant decrease in oxygen $\left(\mathrm{O}_{2}\right)$ tension that potentially constrains aerobic life in such environment. Some of these adaptations include changes in respiratory surfaces, heart size, hemoglobin concentration ([Hb]), hematocrit (Hct), capillary density, and myoglobin levels (Morrison 1964; Bouverot 1985; Monge and Leon-Velarde 1991; Weber 1995; Samaja et al. 2003; Nikinmaa 2013). Hematological data from high-altitude (>3000 m) and low-altitude species have shown changes that suggest adaptations to this environment in some vertebrate taxa, but not in others (Ruiz et al. 1993).

Received 30 September 2014. Accepted 27 February 2015

J.C. González-Morales. Facultad de Ciencias, Universidad Autónoma del Estado de México, Instituto Literario No. 100, Col. Centro, Toluca, Estado de México, México.

E. Quintana. Centro Tlaxcala de Biología de la Conducta, Universidad Autónoma de Tlaxcala, Km. 1.5 Carretera Federal Tlaxcala-Puebla, Tlaxcala, Tlax., México.

H. Díaz-Albiter. Fundação Oswaldo Cruz. Av. Brasil, 4365 - Manguinhos, Rio do Janeiro, 10 Brasil.

P. Guevara-Fiore. Escuela de Biología. Benemérita Universidad Autónoma de Puebla, Blvd. Valsequillo y Av. San Claudio Edificio 112-A, Ciudad Universitaria, Col. Jardines de San Manuel, Puebla, México.

V. Fajardo. Facultad de Medicina Veterinaria y Zootecnia, Universidad Autónoma del Estado de México, Instituto Literario No. 100, Col. Centro, Toluca, Estado de México, México.

Corresponding author: Victor Fajardo (e-mail: fajardo.vic@gmail.com). 
With a few exceptions (Storz et al. 2010), most of the studies in homoeothermic mammals have demonstrated a positive correlation between erythrocyte count $(\mathrm{Erc})$ and $\mathrm{Hb}$ content, and between Erc and altitude. However, information in reptiles is still contradictory (Duguy 1970; Bouverot 1985). Some studies have shown little or no correlation between blood values (i.e., Erc, Hct, [Hb]) in lizards and altitudinal distribution (Dawson and Poulson 1962; Dessauer 1970; Biswas et al. 1981, Ruiz et al. 1983, 1993; Weber 2007; He et al. 2013). For example, Mexican spiny lizards of the genus Sceloporus Wiegmann, 1828 found at lowlands $(61 \mathrm{~m}$ above sea level (asl)) and highlands (3100 m asl) have shown no differences in lactate levels, which suggests that they both exhibit similar patterns of anaerobic activity (Bennett and Ruben 1975). Others have reported increased hematological values $(\mathrm{Hb}$, Erc, Hct, etc.) in highland lizards (Vinegar and Hillyard 1972; Weathers and White 1972; Engbretson and Hutchinson 1976; Newlin and Ballinger 1976). In the Zodiac Tree Iguana (Liolaemus multiformis (Dumèril and Bibron 1837)), higher Erc, Hct, and [Hb] were observed in individuals found in high altitudes (Eby and Banchero 1976). However, information regarding erythrocyte morphology and size is scarce and most studies are comparisons between species (Arikan and Cicek 2010; Vaissi et al. 2013). Some authors have reported changes in erythrocyte size (Ers) in fish (Srivastava and Griffith 1974) and anurans (Ruiz et al. 1989; Baraquet et al. 2013) in hypoxic environments. Others have suggested that changes in Ers might be a response to avoid hypoxia in lizards (He et al. 2013) and chicken embryos (Tazawa et al. 2012).

Wiegmann's Torquate Lizard (Sceloporus torquatus Wiegmann, 1828) represents an excellent model to study altitudinal effects on blood parameters. This species naturally occurs over a wide altitudinal range (1500-3500 $\mathrm{m}$ above sea level (asl)) in the State of Mexico. Here, we examined Ers of $S$. torquatus from four populations found at different altitudes. Hct, $[\mathrm{Hb}]$, and other blood parameters were also compared and evaluated. We predicted that the high-altitude lizards would show increases in hematological values in response to hypoxia and its associated decrease in $\mathrm{O}_{2}$ partial pressure. We also expected to find a strong correlation between all hematological parameters and altitude.

\section{Materials and methods}

\section{Ethics statement}

All experimental procedures were carried out according to the Canadian Council on Animal Care guidelines, as well as the Mexican Federal Regulation for Animal Experimentation and Care (NOM-062-ZOO-2001).

\section{Field sites and animals}

After governmental approval (SGPA/DGVS/02407/13), 10 lizards from Malinalco $\left(18^{\circ} 57^{\prime} \mathrm{N}, 99^{\circ} 30^{\prime} \mathrm{W} ; 1595 \pm 43 \mathrm{~m}\right.$ asl), 10 lizards from Temascaltepec $\left(19^{\circ} 26^{\prime} \mathrm{N}, 100^{\circ} 24^{\prime} \mathrm{W} ; 1732 \pm 16 \mathrm{~m}\right.$ asl), 10 lizards from Ixtlahuaca $\left(19^{\circ} 34^{\prime} \mathrm{N}, 99^{\circ} 46^{\prime} \mathrm{W} ; 2505 \pm 27 \mathrm{~m}\right.$ asl), and $20 \mathrm{liz}-$ ards from Cerro de Coatepec $\left(19^{\circ} 17^{\prime} \mathrm{N}, 99^{\circ} 39^{\prime} \mathrm{W} ; 2714 \pm 10 \mathrm{~m}\right.$ asl) were collected. Only adults were selected for the study. Animals were captured by hand. To avoid handling and stress-related differences, only specimens captured within $15 \mathrm{~min}$ of first sighting were used for the study. Altitude was registered at the capture site (GPS Etrex Vista; Garmin, Olathe, Kansas, USA).

\section{Blood sampling}

Lizards were sampled 20-30 min after capture. During this time, specimens were maintained in cages with lamps at $25^{\circ} \mathrm{C}$. Animals were anaesthetized using intramuscularly injected ketamine (70 mg/kg), and body mass and snout-vent length (SVL) were measured. Additionally, body temperature was measured for blood-electrolyte-analysis correction. Approximately $300 \mu \mathrm{L}$ of blood were drawn from the aortic arch into heparinized (lithium heparin) sterile tubes. Samples were stored in a thermal container and transported to the behavioral physiology laboratory of the
Facultad de Medicina Veterinaria y Zootecnia. Specimens were then euthanized with an overdose of anesthetic via intracardiac infusion because the heart, striated muscles, lungs, and stomach were intended for other studies.

\section{Blood parameters}

Erc were performed with a Neubauer hemocytometer. Blood smears were stained with Wright's stain to reveal erythrocyte. Forty erythrocytes per animal were photographed under $\times 100$ magnification using a light microscope (model BX41TF; Olympus Corporation, Tokyo, Japan) and a digital camera system with detail enhancement (model E-330; Olympus Corporation, Tokyo, Japan). Images were transferred via firewire interface cable (IEEE 1394 DV) to a computer (precision T3400; Dell Inc., Round Rock, Texas, USA).

Hct was determined as percentage of packed cell volume by centrifuging blood samples in a microhematocrit tube for $7 \mathrm{~min}$ at 14890g. $[\mathrm{Hb}]$ was determined as cyanmethemoglobin using the Hycel cyanmethemoglobin reagent and a Bausch and Lomb Spectronic 20 colorimeter. MCHC was calculated using the formula $100 \times[\mathrm{Hb}] /$ Hct. To evaluate Ers, we measured erythrocyte area from digitized micrographs using the Sigma Scan Pro software version 4 for Windows (Systat Software Inc., San Jose, California, USA). Seven fields and a minimum of 70 random erythrocyte cells were measured per animal at each altitude.

To determine $\mathrm{pH}$, serum electrolytes sodium $\left(\mathrm{Na}^{+}\right)$, potassium $\left(\mathrm{K}^{+}\right)$, and calcium $\left(\mathrm{Ca}^{2+}\right)(\mathrm{mmol} / \mathrm{L})$, as well as glucose $(\mathrm{mg} / \mathrm{dL})$ and lactate $(\mathrm{mg} / \mathrm{dL}), 200 \mu \mathrm{L}$ of blood were processed using a blood electrolyte analyzer (GEM Premier 3000; Instrumentation Laboratory Diagnostics, Bedford, Massachusetts, USA). For this test, samples were assayed within $3 \mathrm{~h}$ after sampling. Lizards were divided into two groups: highland (Ixtlahuaca and Cerro de Coatepec) and lowland (Malinalco and Temascaltepec).

\section{Statistical analysis}

Descriptive statistics are shown as means \pm SE. An one-way ANOVA was used for comparison of Erc, Hct, [Hb], MCHC, and Ers, while Tukey-Kramer post hoc tests were performed to identify the nature of the statistical differences. Additionally, the significance of correlations between Erc, Hct, [Hb], MCHC, and Ers values and altitude was tested using Pearson's correlation coefficient. Student's $t$ test was used to compare glucose and electrolytes (JMP software version 4 for Windows; SAS Institute Inc., Cary, North Carolina, USA). All tests were two-tailed, and differences or correlations were considered significant when $p<0.05$. Since no sexual differences in any blood parameters were observed, both males and females were used in all experiments.

\section{Results}

\section{Animals}

Mass and SVL data of animals are summarized in Table 1.

\section{Blood parameters}

Figures $1 a$ and $1 b$ shows Erc in populations from different altitudes. There were significant differences between the two lowland populations (Malinalco at $\sim 1595 \mathrm{~m}$ asl and Temascaltepec at $\sim 1732 \mathrm{~m}$ asl) and the two highland populations (Ixtlahuaca at $\sim 2505 \mathrm{~m}$ asl and Cerro de Coatepec at $\sim 2714 \mathrm{~m}$ asl). Interestingly, statistical analysis shows differences between the two highland populations. Cerro de Coatepec lizards show a lower Erc than Ixtlahuaca but higher than lowland populations (Fig. 1a; $\mathrm{F}_{[3,46]}=$ $36.917 p<0.001)$. Furthermore, we found a significant correlation between Erc and altitude (Fig. 1b).

Hct was different between lowland and highland populations, and exhibited a similar tendency to Erc results (Fig. $2 a ; \mathrm{F}_{[3,46]}=$ $10.57 p<0.001)$. Additionally, we found a significant correlation between Hct and altitude (Fig. $2 b$ ). 
Table 1. Morphological parameters of Wiegmann's Torquate Lizards (Sceloporus torquatus).

\begin{tabular}{lllll}
\hline & $\begin{array}{l}\text { Malinalco } \\
(1595 \pm 43 \mathrm{~m} \text { asl })\end{array}$ & $\begin{array}{l}\text { Temascaltepec } \\
(1732 \pm 16 \mathrm{~m} \text { asl })\end{array}$ & $\begin{array}{l}\text { Ixtlahuaca } \\
(2505 \pm 27 \mathrm{~m} \text { asl })\end{array}$ & $\begin{array}{l}\text { Cerro de Coatepec } \\
(2714 \pm 10 \mathrm{~m} \text { asl })\end{array}$ \\
\hline Snout-vent length (SVL; mm) & $91.50 \pm 0.06$ & $81.76 \pm 1.87$ & $83 \pm 6.12$ & $86.04 \pm 1.63$ \\
Body mass $(\mathrm{g})$ & $21.32 \pm 1.64$ & $20.97 \pm 1.91$ & $23.88 \pm 1.82$ & $20.97 \pm 1.24$ \\
\hline
\end{tabular}

Note: Values are means \pm SE. asl, above sea level.

Fig. 1. (a) Erythrocyte counts (Erc; mean \pm SE) in Wiegmann's Torquate Lizards (Sceloporus torquatus) from different altitudes. Highland lizards (2505 \pm 27 and $2714 \pm 10 \mathrm{~m}$ above sea level (asl)) show higher Erc than lowland lizards (1595 \pm 43 and $1732 \pm 16 \mathrm{~m}$ asl). (b) Pearson’s correlation coefficient between altitude and Erc: $r=0.76, p<0.001$.

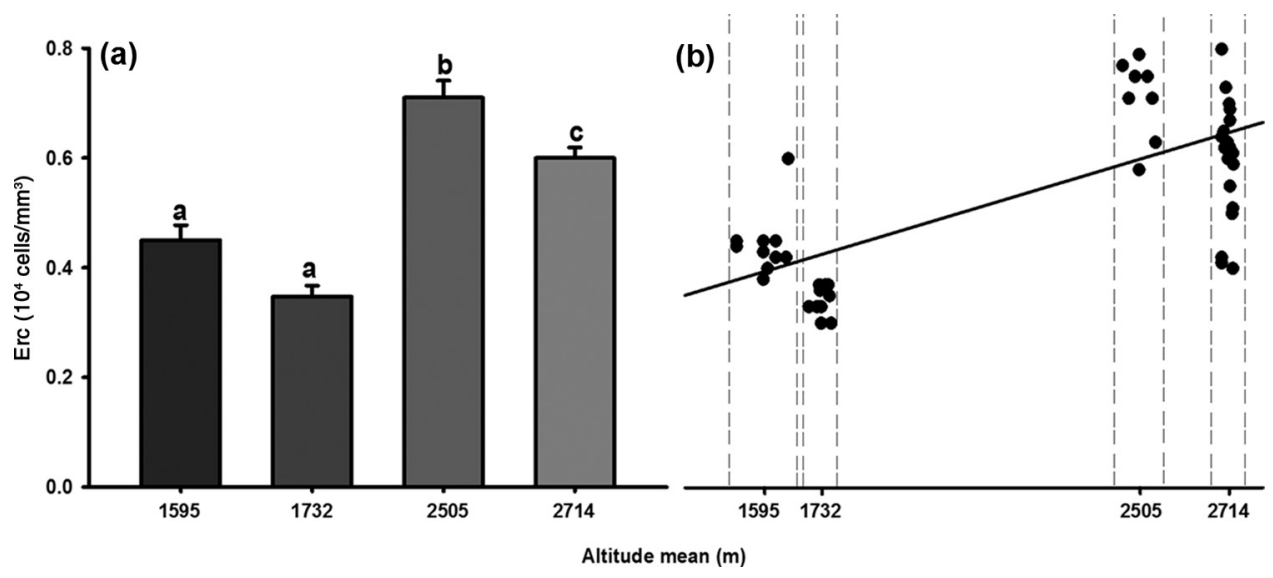

Fig. 2. (a) Hematocrit percentage (Hct; mean \pm SE) in Wiegmann's Torquate Lizards (Sceloporus torquatus) from different altitudes. Highland lizards (2505 \pm 27 and $2714 \pm 10 \mathrm{~m}$ above sea level (asl)) exhibit higher Hct than lowland lizards (1595 \pm 43 and $1732 \pm 16 \mathrm{~m}$ asl). (b) Pearson's correlation between altitude and Hct: $r=0.417, p<0.001$.
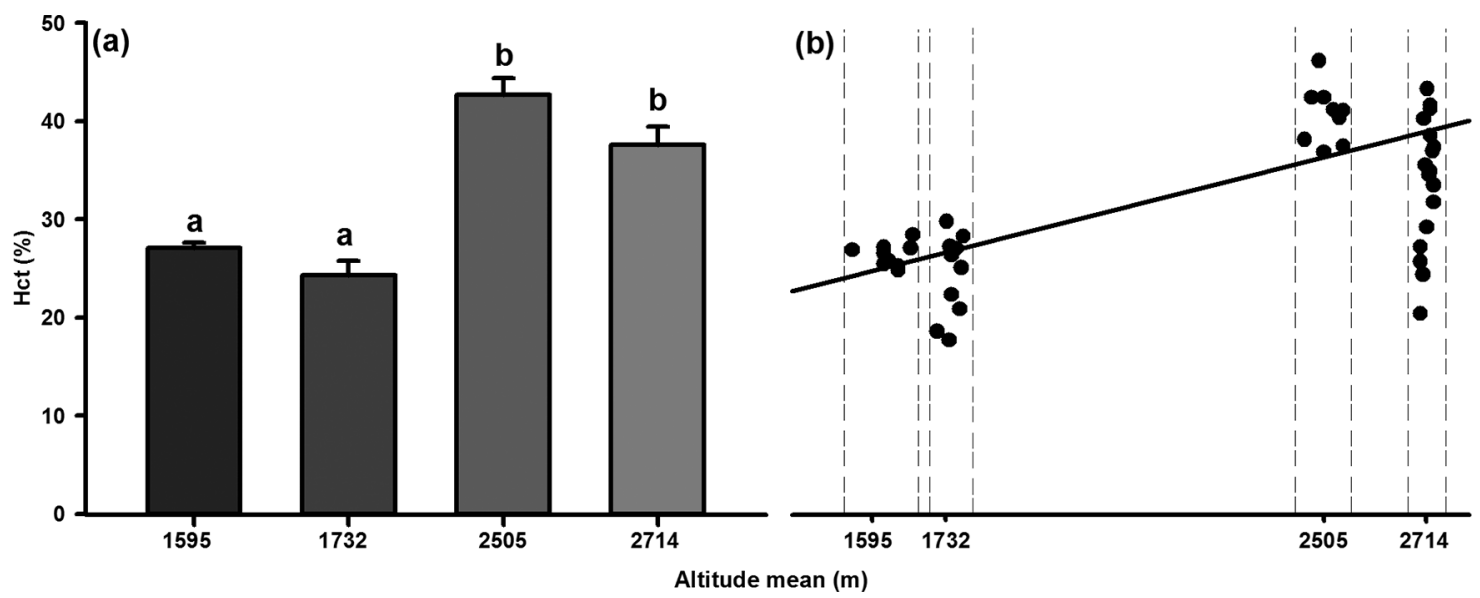

$[\mathrm{Hb}]$ increased with altitude. Highland populations exhibited significantly higher $[\mathrm{Hb}]$ values than lowland ones (Fig. $3 a ; F_{[3,46]}=$ $22.78 p<0.001)$. $[\mathrm{Hb}]$ and altitude exhibited a significant correlation (Fig. 3b).

MCHC differed significantly among populations. However, the MCHC showed no difference between the populations at $1732 \mathrm{~m}$ asl (Temascaltepec) and at $2714 \mathrm{~m}$ asl (Cerro de Coatepec). Also, no differences were observed between populations at $1595 \mathrm{~m}$ asl (Malinalco) and at $2505 \mathrm{~m}$ asl (Ixtlahuaca) (Fig. 4a; $\mathrm{F}_{[3,46]}=6.63$ $p<0.001$ ) and no correlation was observed between MCHC with altitude (Fig. 4b).

Similar to $[\mathrm{Hb}]$, Ers showed a significant increase with altitude. Erythrocytes from lizards found at the lowest altitude (Malinalco) were significantly smaller than erythrocytes from all other populations. Erythrocytes from lizards collected at the highest altitude (Cerro de Coatepec) showed a significant increase in area compared with all other populations (Fig. $5 a ; F_{[3,3496]}=273.26 p<0.001$ ).
Additionally, a positive and significant correlation between altitude and Ers was found (Fig. 5b).

Values of glucose lactate, $\mathrm{pH}$, and electrolytes are summarized in Table 2. Only glucose and $\mathrm{pH}$ were similar between lowland and highland animals; all other parameters showed statistically significant differences.

\section{Discussion}

This is the first study to use the same species in an altitudinal gradient to describe and compare blood parameters in a lizard. Our results exhibited a significant increase in Erc, Hct, [Hb], and Ers in highland populations. MCHC showed no correlation with altitude. Additionally, significant differences in lactate, $\mathrm{Na}^{+}, \mathrm{K}^{+}$, and $\mathrm{Ca}^{2+}$ were observed.

In lizards, Dunlap (2006) showed that as body size increases, Hct increases allometrically. In our results, Hct increased in highland 
Fig. 3. (a) Hemoglobin concentration ([Hb]; mean \pm SE) in Wiegmann's Torquate Lizards (Sceloporus torquatus) from different altitudes. Highland lizards (2505 \pm 27 and $2714 \pm 10 \mathrm{~m}$ above sea level (asl)) show higher [Hb] than lowland lizards (1595 \pm 43 and $1732 \pm 16 \mathrm{~m}$ asl). (b) Pearson's correlation between altitude and [Hb]: $r=0.727, p<0.001$.

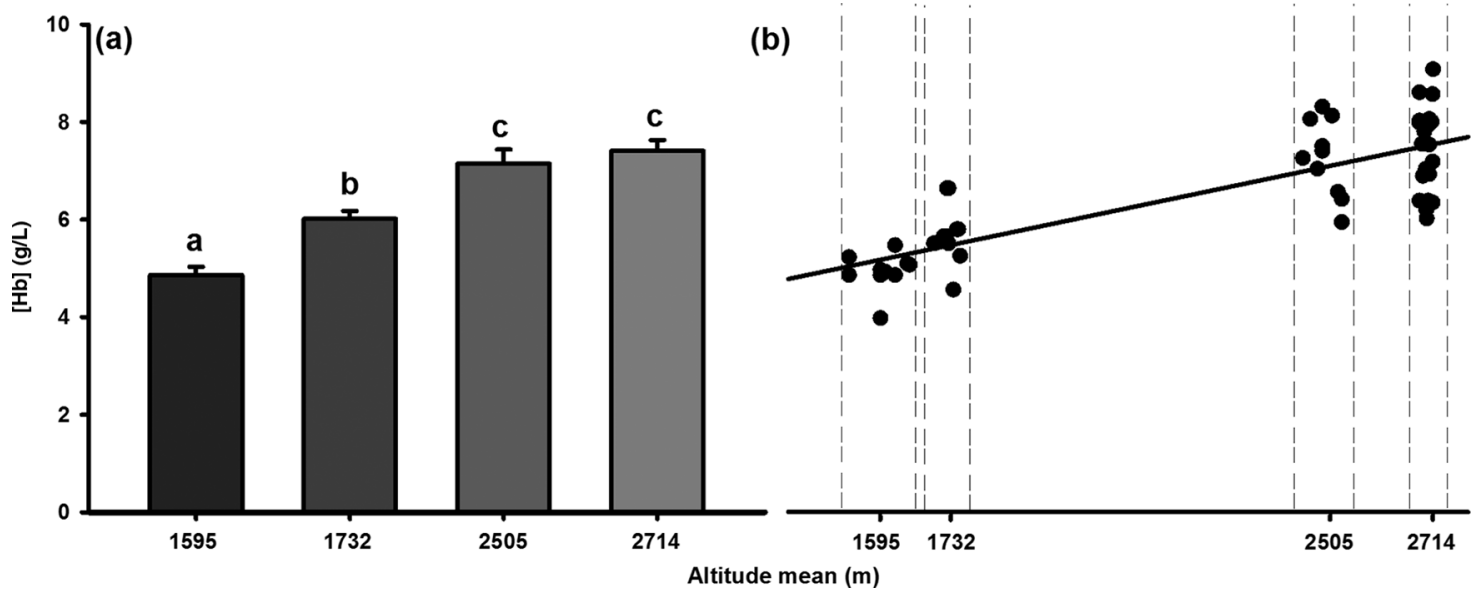

Fig. 4. (a) Mean corpuscular hemoglobin concentration (MCHC; mean \pm SE) in Wiegmann's Torquate Lizards (Sceloporus torquatus) from different altitudes. Lizards from $1732 \pm 16$ and $2714 \pm 10 \mathrm{~m}$ above sea level (asl) show higher MCHC than lizards from $1595 \pm 43$ and $2505 \pm 27 \mathrm{~m}$ asl. (b) Pearson's correlation between altitude and MCHC: $r=0.02, p>0.05$.

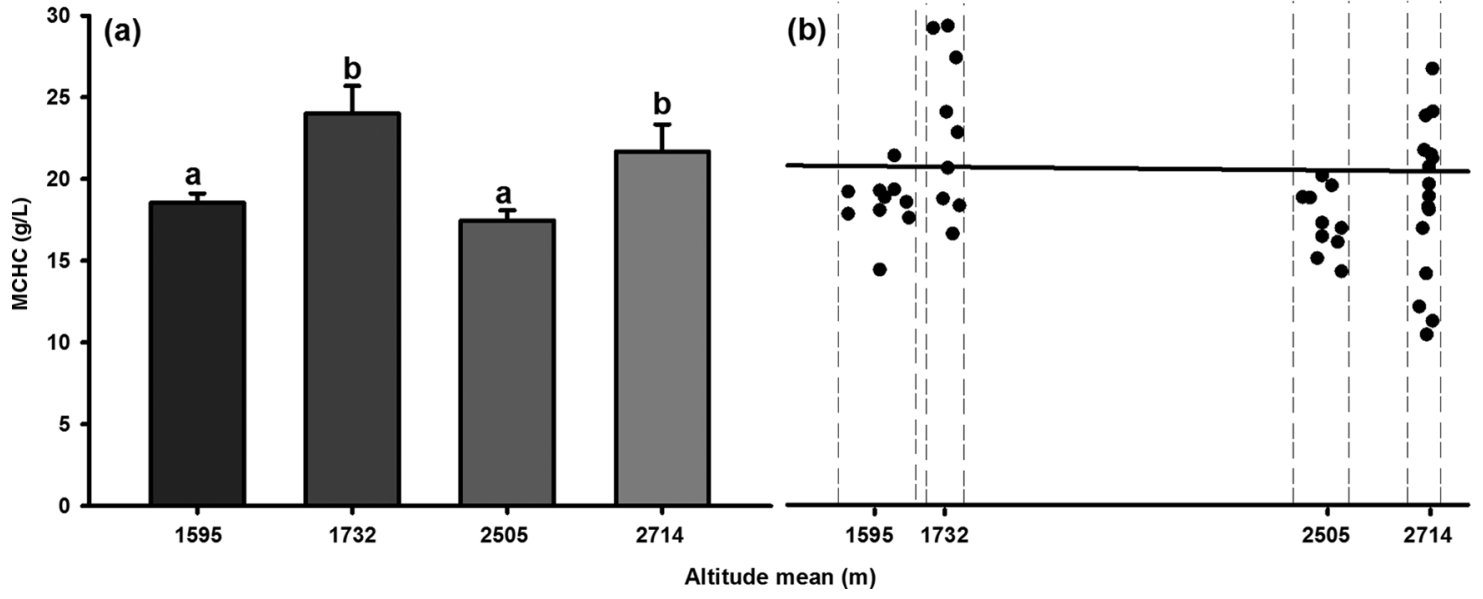

Fig. 5. (a) Erythrocyte size (Ers; mean \pm SE) in Wiegmann's Torquate Lizards (Sceloporus torquatus) from different altitudes. Highland lizards (2505 \pm 27 and $2714 \pm 10 \mathrm{~m}$ above sea level (asl)) show higher Ers than lowland lizards (1595 \pm 43 and $1732 \pm 16 \mathrm{~m}$ asl). (b) Pearson's correlation between altitude and Ers: $r=0.573, p<0.001$.
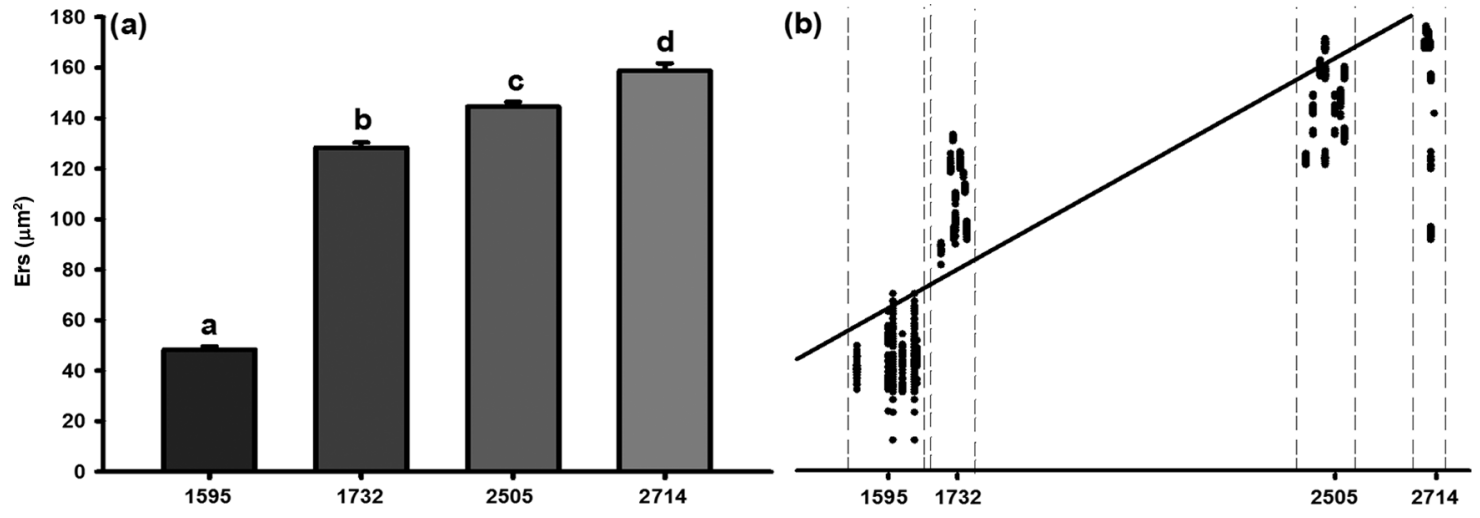

lizards, but not allometrically, because animals from different elevations showed similar size and mass. Furthermore, similar results in the Western Fence Lizard (Sceloporus occidentalis Baird and Girard, 1852) regarding Erc and Hct were observed by Weathers and White (1972). The authors found that [Hb] was similar between lowland (2750 $\mathrm{m}$ asl) and highland (3200 $\mathrm{m}$ asl) lizards. Our findings were similar regarding an increment in Erc with altitude (Fig. 1a). In contrast, we did observe increased [Hb] concentration 
Table 2. Glucose, lactate, and electrolyte concentrations, as well as $\mathrm{pH}$, in lowland and highland populations of Wiegmann's Torquate Lizards (Sceloporus torquatus).

\begin{tabular}{lll}
\hline & Lowland & Highland \\
\hline Glucose $(\mathrm{mg} / \mathrm{dL})$ & $162.66 \pm 2.19$ & $176.50 \pm 14.12$ \\
Lactate $(\mathrm{mmol} / \mathrm{L})$ & $5.96 \pm 0.81$ & $9.90 \pm 1.17^{*}$ \\
$\mathrm{pH}$ & $7.27 \pm 0.04$ & $7.28 \pm 2.19$ \\
$\mathrm{Na}^{+}(\mathrm{mmol} / \mathrm{L})$ & $115.33 \pm 4.58$ & $153.25 \pm 1.54^{* * *}$ \\
$\mathrm{~K}^{+}(\mathrm{mmol} / \mathrm{L})$ & $2.06 \pm 0.46$ & $8.67 \pm 1.34^{* * *}$ \\
$\mathrm{Ca}^{2+}(\mathrm{mmol} / \mathrm{L})$ & $0.21 \pm 0.07$ & $0.98 \pm 0.14^{* * *}$ \\
\hline \multicolumn{2}{c}{ Note: Values are means $\pm \mathrm{SE} .{ }^{*}, p<0.05 ;{ }^{* * *}, p<0.001}$.
\end{tabular}

in highland populations compared with lowland populations (Fig. 3a). Sheeler and Barber (1965) reported that [Hb] is directly proportional to the packed cell volume. Our results support this idea. Furthermore, Vinegar and Hillyard (1972) showed changes in Erc and $[\mathrm{Hb}]$ between Yarrow's Spiny Lizards (Sceloporus jarrovi Cope, 1875) found at 1554 and $1828 \mathrm{~m}$ asl. However, no differences in either parameter were observed between lizards found at 1828 and $2621 \mathrm{~m}$ asl. In our study, altitude differences of $137 \mathrm{~m}$ asl appeared to be sufficient to trigger changes in $[\mathrm{Hb}]$ between lowland Malinalco and Temascaltepec populations. In contrast, an altitude difference of $209 \mathrm{~m}$ asl between highland Ixtlahuaca and Cerro de Coatepec populations seemed not to have the same effect. This might be due to the sample size. Further studies with an increased number of individuals might help in understanding this phenomenon.

Similar results for $[\mathrm{Hb}]$ were reported by Newlin and Ballinger (1976) in three species of Sceloporus: the Crevice Spiny Lizard (Sceloporus poinsetti Baird and Girard, 1852) living at $1420 \mathrm{~m}$ asl, the Striped Plateau Lizard (Sceloporus virgatus Smith, 1938) living at $1650 \mathrm{~m}$ asl, and the Light-bellied Bunch Grass Lizard (Sceloporus scalaris Wiegmann, 1828) living at $2560 \mathrm{~m}$ asl. Newlin and Ballinger (1976) also compared $[\mathrm{Hb}]$ in the Ornate Tree Lizard (Urosaurus ornatus (Baird and Girard, 1852)) living at different altitudes (1450 and $1830 \mathrm{~m}$ asl) and no changes were observed. Similarly, Ruiz et al. (1993) compared hematological parameters in 27 species of lizards living in different altitudes and found no differences in any on them. However, no species of Sceloporus were considered in that study. It is possible that such changes in blood parameters in response to altitude could be exclusive to the genus Sceloporus. More analyses with more species of Sceloporus are necessary to find out whether this is an exclusive feature of this group.

The major function of erythrocytes is to transport $\mathrm{Hb}-$ bound $\mathrm{O}_{2}$ from lungs to all tissues of the body. Increasing blood transport of $\mathrm{O}_{2}$ is an alternative mechanism to maintain $\mathrm{O}_{2}$ availability in hypoxic environments. Higher hematological parameters can increase $\mathrm{O}_{2}$ transport (Vinegar and Hillyard 1972; Ruiz et al. 1983). An increase in erythrocyte numbers in hypoxic environments can help to increase $\mathrm{O}_{2}$ transport to sites of $\mathrm{O}_{2}$ consumption within the organism. For example, in northern elephant seals (Mirounga angustirostris (Gill, 1866)), an increase in Hct is associated with increased blood $\mathrm{O}_{2}$ transport and $\mathrm{O}_{2}$ storage capacity (Hedrick et al. 1986). However, this can also lead to an increment in blood viscosity (Hedrick et al. 1986; He et al. 2013). Furthermore, high Hct achieved through an increased number of erythrocytes is not necessarily associated with high attainable aerobic power output (Crowell et al. 1959; Crowell and Smith 1967; Villafuerte et al. 2004; Schuler et al. 2010). This is because the associated increase in blood viscosity produces a higher peripheral vascular resistance that might compromise cardiac blood output, thereby reducing the rate of $\mathrm{O}_{2}$ consumption by tissues (Guyton and Richardson 1961; Connes et al. 2006). However, $\mathrm{O}_{2}$ affinity of $\mathrm{Hb}$ can be modified by adjusting intraerythrocytic conditions (cell size, for example), and accordingly, [Hb] (Nikinmaa 1997; see Bogdanova et al. 2009). It is possible that highland animals used in this study had higher blood viscosity compared with lowland animals, and that, to avoid vascular resistance, the highland lizards modify Ers. Consequently, the increase in erythrocyte area that we found might be interpreted as a strategy to prevent hypoxia which avoids increasing blood viscosity, as described in chicken embryos (Tazawa et al. 2012).

Our results suggest that higher erythrocyte area and $\mathrm{Hb}$ content from highland populations of $S$. torquatus could be an adaptation to cope with hypoxia. High-altitude species are challenged by at least two factors: low partial pressures of $\mathrm{O}_{2}$ and low environmental temperatures. MacLean et al. (1975) have shown that low temperature results in lower Hct. Vinegar and Hillyard (1972) showed that the blood of highland species of Sceloporus does contain more $\mathrm{Hb}$ than lowland ones. These values may constitute an adaptive response to the increased metabolic rate and shorter, cooler growing season. Our results support this idea. Highlands considered in this study have annual temperatures ranging from 0 to $18{ }^{\circ} \mathrm{C}$, whereas lowland temperatures range from 10 to $25{ }^{\circ} \mathrm{C}$. Future blood parameter studies where animals occurring at high-altitude areas are transferred to low-altitude areas and vice versa could help in understanding if this phenomenon is an adaptation or acclimatization.

On the other hand, the results of MCHC showed that the population of Temascaltepec and Cerro de Coatepec had increased values relative to the other populations that we studied. MCHC has been linked to $\mathrm{O}_{2}$ saturation capacity, which explain the high values obtained for the animals of the high-altitude, hypoxic site at Cerro de Coatepec. Similar patterns have been demonstrated in other animals (e.g., the toad Bufo spinulosus Wiegmann, $1834=$ Rhinella spinulosa (Wiegmann, 1834): Ruiz et al. 1989; yaks (Bos grunniens L., 1766): Ding et al. 2014). But this explanation does not account for the MCHC levels observed in Temascaltepec (a relatively low-altitude population). The animals of Temascaltepec showed a tendency to have lower Erc and Hct, thus, we believe that the animals of Temascaltepec have a different strategy to avoid hypoxia. That is, they exhibit reduced Erc and Hct but higher [Hb]. They also apparently exhibit greater saturation of $\mathrm{O}_{2}$, revealed by the greater MCHC, which may increase $\mathrm{O}_{2}$ capacity without the disadvantage of higher Hct that may increase blood viscosity (Ashby 1985).

It has been shown that hypoxic environments lead to an increase in blood lactate (see Lundby et al. 2000). Because lactate production provides most of the energy generation during rapid activity, lactate is associated with anaerobic activity (Bennett and Ruben 1975). In our results, highland lizards showed higher lactate levels than lowland lizards. This could be a consequence of an increase in anaerobic metabolism in highland populations. Furthermore, lactate accumulation is an adaptation to resist the low temperatures of highland environments (see Jackson 2007). We also observed differences in ion concentrations. Increments in blood $\mathrm{Na}^{+}$, $\mathrm{K}^{+}$, and $\mathrm{Ca}^{2+}$ in humans exposed to highland environments have been described (Williams 1966). Furthermore, erythrocytes swell when blood $\mathrm{K}^{+}$is increased, while the opposite happens when blood $\mathrm{K}^{+}$decreases (see Lang et al. 1998). Our results show a high concentration of $\mathrm{K}^{+}$in highland lizards. Thus, the increased erythrocyte area observed could be due to an increment in blood $\mathrm{K}^{+}$. High concentrations of blood $\mathrm{K}^{+}$have also been associated with a reduction of muscle fatigue, as well as maintenance of cardiac rate, in hypoxic environments (Riddick et al. 1971; Sejersted and Sjøgaard 2000).

In conclusion, most hematological parameters were significantly different among lizard populations from different altitudes. This is the first study to report changes in Ers in relation to altitude, which could be a physiological response to hypoxia in $S$. torquatus. Comparisons between our results and previous work suggest that there are probably multiple strategies to avoid hypoxia in reptiles. 


\section{Acknowledgements}

We thank the Consejo Nacional de Ciencia y Tecnología (grant 178723) for financial support and the Secretaría de Medio Ambiente y Recursos Naturales for the permission to collect animals (SGPA/DGVS/02407/13). We are also thankful to the anonymous reviewers for their valuable comments, E. Bastiaans for language corrections, and M. Pichardo and J. Mata for bibliographical and technical assistance.

\section{References}

Arikan, H., and Cicek, K. 2010. Morphology of peripheral blood cells of various species of Turkish herpetofauna. Acta Herpetol. 5(2): 179-198.

Ashby, M.D. 1985. Factors affecting blood physiology and haemoglobin function in the New Zealand Skinks, Leiolopisma smithi (Gray) and Leiolopisma zelandica (Gray). Comp. Biochem. Physiol. Part A Physiol. 80: 31-40. doi:10.1016/03009629(85)90673-5.

Baraquet, M., Grenat, P.R., Salas, N.E., and Martino, A.L. 2013. Intraspecific variation sizes among populations of Hypsiboas cordobae (Anura: Hylidae). Acta Herpetol. 8(2): 93-97.

Bennett, A.F., and Ruben, J. 1975. High altitude adaptation and anaerobiosis in sceloporine lizards. Comp. Biochem. Physiol. Part A Physiol. 50(1): 105-108. doi:10.1016/S0010-406X(75)80209-X.

Biswas, H.M., Patra, B.B., and Boral, M.C. 1981. Body fluid and hematological changes in the toad exposed to $48 \mathrm{~h}$ of simulated high altitude. J. Appl. Physiol. 51(4): 794-797. PMID:7298419.

Bogdanova, A., Berenbrink, M., and Nikinmaa, M. 2009. Oxygen-dependent ion transport in erythrocytes. Acta Physiol. 195: 305-319. doi:10.1111/j.1748-1716. 2008.01934.x.

Bouverot, P. 1985. Adaptation to altitude-hypoxia in vertebrates. SpringerVerlag, Berlin.

Connes, P., Yalcin, O., Baskert, O., Brun, J.F., and Hardeman, M. 2006. In health and in a normoxic environment, $\mathrm{VO}_{2} \mathrm{max}$ is/is not limited primarily by cardiac output and locomotor muscle blood flow. J. Appl. Physiol. 100(6): 2099. doi:10.1152/japplphysiol.00279.2006.

Crowell, J.W., and Smith, E.E. 1967. Determinants of the optimal hematocrit. J. Appl. Physiol. 22: 501-504.

Crowell, J.W., Ford, R.G., and Lewis, V.M. 1959. Oxygen transport in hemorrhagic shock as a function hematocrit ratio. Am. J. Physiol. 196(5): 1033-1038. PMID: 13649925.

Dawson, W.R., and Poulson, T.L. 1962. Oxygen capacity of lizard bloods. Am. Midl. Nat. 68: 154-164. doi:10.2307/2422642.

Dessauer, H.C. 1970. Blood chemistry of reptilians. In Biology of the Reptilia. Edited by C. Gans and T. Parsons. Academic Press, New York. pp. 156-168.

Ding, X.Z., Liang, C.N., Guo, X., Wu, X.Y., Wang, H.B., Johnson, K.A., and Yan, P. 2014. Physiological insight into the high-altitude adaptations in domesticated yaks (Bos grunniens) along the Qinghai-Tibetan Plateau altitudinal gradient. Livest. Sci. 162: 233-239. doi:10.1016/j.livsci.2014.01.012.

Duguy, R. 1970. Numbers of blood cells and their variation. In Biology of the Reptilia. Edited by C. Gans and T. Parsons. Academic Press, New York. pp. 128-135.

Dunlap, K.D. 2006. Ontogeny and scaling of hematocrit and blood viscosity in western fence lizards Sceloporus occidentalis. Copeia, 2006(3): 535-538. doi:10. 1643/0045-8511(2006)2006[535:OASOHA]2.0.CO;2.

Eby, S.H., and Banchero, N. 1976. Capillary density of skeletal muscle in Andean dogs. Proc. Soc. Exp. Biol. Med. 151(4): 795-798. doi:10.3181/00379727-15139309.

Engbretson, G., and Hutchinson, V. 1976. Erythrocyte count, hematocrit and hemoglobin content in lizard Liolaemus multiformis. Copeia, 1976: 186. doi:10. $2307 / 1443789$

Guyton, A.C., and Richardson, T.Q. 1961. Effect of hematocrit on venous return. Circ. Res. 9: 157-164. doi:10.1161/01.RES.9.1.157.

He, J., Xiu, M., Tang, X., Yue, F., Wang, N., Yang, S., and Chen, Q. 2013. The different mechanisms of hypoxic acclimatization and adaptation in lizard Phrynocephalus vlangalii living on Quinghai-Tibet Plateau. J. Exp. Zool. 319(3): 117-123. doi:10.1002/jez.1776.

Hedrick, M.S., Duffield, D.A., and Cornell, L.H. 1986. Blood viscosity and optimal hematocrit in a deep-diving mammal, the northern elephant seal (Mirounga angustirostris). Can. J. Zool. 64(10): 2081-2085. doi:10.1139/z86-317.

Jackson, D. 2007. Temperature and hypoxia in ectothermic tetrapods. J. Therm. Biol. 32: 125-133. doi:10.1016/j.jtherbio.2007.01.007.

Lang, F., Busch, G.L., Ritter, M., Volkl, H., Waldegger, S., Gulbins, E., and Haussinger, D. 1998. Functional significance of cell volume regulatory mechanisms. Physiol. Rev. 78(1): 247-306. PMID:9457175.

Lundby, C., Saltin, B., and van Hall, G. 2000. The "lactate paradox", evidence for a transient change in the course of acclimatization to severe hypoxia in lowlanders. Acta Physiol. Scand. 170: 265-269. doi:10.1046/j.1365-201x.2000. 00785.x. PMID:11450136.

MacLean, G., Lee, A.K., and Withers, P.C. 1975. Haematological adjustment with diurnal changes in body temperature in a lizard and a mouse. Comp. Biochem. Physiol. Part A Physiol. 51: 241-249. doi:10.1016/0300-9629(75)90443-0.

Monge, C., and Leon-Velarde, F. 1991. Physiological adaptation to high altitude: oxygen transport in mammals and birds. Physiol. Rev. 71(4): 1135-1172. PMID: 1924550

Morrison, P. 1964. Wild animals at high altitudes. Symp. Zool. Soc. (Lond.), 13: 49-55.

Newlin, M., and Ballinger, R. 1976. Blood hemoglobin concentration in four species of lizards. Copeia, 1976: 392-394. doi:10.2307/1443975.

Nikinmaa, M. 1997. Oxygen and carbon dioxide transport in vertebrates erythrocytes: an evolutionary change in the role of membrane transport. J. Exp. Biol. 200(2): 369-380. PMID:9050246.

Nikinmaa, M. 2013. What is hypoxia? Acta Physiol. 209: 1-4. doi:10.1111/apha. 12146.

Riddick, D.H., Krengenow, F.M., and Orloff, J. 1971. The effect of norepinephrine and dibutyryl cyclic adenosine monophosphate on cation transport in duck erythrocytes. J. Gen. Physiol. 57: 752-766. doi:10.1085/jgp.57.6.752.

Ruiz, G., Rosenmann, M., and Veloso, A. 1983. Respiratory and haematological adaptation to high altitude in Telmatobius frog from Chilean Andes. Comp. Biochem. Part A Physiol. 76: 109-114. doi:10.1016/0300-9629(83)90300-6.

Ruiz, G., Rosenmann, M., and Veloso, A. 1989. Altitudinal distribution and blood values in the toad, Bufo spinulosus Wiegmann. Comp. Biochem. Part A Physiol. 94(4): 643-646. doi:10.1016/0300-9629(89)90609-9.

Ruiz, G., Rosenmann, M., and Nuñez, H. 1993. Blood values in South American lizards from high and low altitudes. Comp. Biochem. Part A Physiol. 106(4): 713-718. doi:10.1016/0300-9629(93)90386-I.

Samaja, M., Crespi, T., Guazzi, M., and Vandegriff, K.D. 2003. Oxygen transport in blood at high altitude: role of the hemoglobin-oxygen affinity and impact of the phenomena related to hemoglobin allosterism and red cell function. Eur. J. Appl. Physiol. 90(3-4): 351-359. doi:10.1007/s00421-003-0954-8. PMID: 14504945 .

Schuler, B., Arras, M., Keller, S., Rettich, A., Lundby, C., Vogel, J., and Gassmann, M. 2010. Optimal hematocrit for maximal exercise performance in acute and chronic erythropoietin-treated mice. Proc. Natl. Acad. Sci. U.S.A. 107: 419-423. doi:10.1073/pnas.0912924107.

Sejersted, O.M., and Sjøgaard, G. 2000. Dynamics and consequences of potassium shifts in skeletal muscle and heart during exercise. Physiol. Rev. 80: 1411-1481. PMID:11015618.

Sheeler, P., and Barber, A.A. 1965. Reticulocytosis and iron incorporation in the rabbit and turtle: a comparative study. Comp. Biochem. Physiol. 16: 63-76. doi:10.1016/0010-406X(65)90164-7.

Srivastava, A.K., and Griffith, R.W. 1974. Erythrocyte morphology and the ecology of species of Fundulus. Copeia, 1974: 136-141. doi:10.2307/1443015.

Storz, J.F., Scott, G.R., and Cheviron, Z.A. 2010. Phenotypic plasticity and genetic adaptation to high-altitude hypoxia in vertebrates. J. Exp. Biol. 213(24): 41254136. doi:10.1242/jeb.048181.

Tazawa, H., Andrewartha, S.J., and Burggren, W.W. 2012. Acute regulation of hematocrit and blood acid-base balance during severe hypoxic challenges in late chicken embryos (Gallus gallus). Resp. Physiol. Neurobiol. 184: 86-96. doi:10.1016/j.resp.2012.08.002

Vaissi, S., Fathipour, F., Salamat, M.A., Parto, P., and Sharifi, M. 2013. Variations in the size erythrocytes and morphology of four lizard species (Laudakia nupta, Trapelus lessonae, Mabuya aurata and Ophisops elegans) from western Iran. Global Veterinaria, 11(3): 297-301.

Villafuerte, F.C., Cárdenas, R., and Monge, C.C. 2004. Optimal hemoglobin concentration and high altitude: a theoretical approach for Andean men at rest. J. Appl. Physiol. 96(5): 1581-1588. doi:10.1152/japplphysiol.00328.2003.

Vinegar, A., and Hillyard, S.D. 1972. The effects of altitude on oxygen-binding parameters of the blood of the iguanid lizards, Sceloporus jarrovi and Sceloporus occidentalis. Comp. Biochem. Physiol. Part A Physiol. 43: 317-320. doi:10.1016/ 0300-9629(72)90190-9.

Weathers, W.W., and White, F.N. 1972. Hematological observations on populations of the lizard Sceloporus occidentalis from sea level and altitude. Herpetologica, 28(2): 172-175.

Weber, R.E. 1995. Hemoglobin adaptations to hypoxia and altitude: the phylogenetic perspective. In Hypoxia and the brain. Edited by J.R. Sutton, C.S. Houston, and G. Coates. Queen City Printers, Burlington, Vt. pp. 31-44.

Weber, R.E. 2007. High-altitude adaptations in vertebrate hemoglobins. Resp. Physiol. Neurobiol. 158(2-3): 132-142. doi:10.1016/j.resp.2007.05.001.

Williams, E.S. 1966. Electrolyte regulation during the adaptation of humans to life at high altitude. Proc. R. Soc. B Biol. Sci. 165: 266-280. doi:10.1098/rspb. 1966.0068 